УДК 616-06:616-079.66:122:167.7

DOI 10.11603/2311-9624.2019.4.10877

(С. П. Брехлічук, П. О. Майструк

ДВН3 «Ужгородський національний університет» e-mail: brekhlichuk@gmail.com

\title{
Ендодонто-ендоосальна імплантація у сучасній стоматології: можливості, проблеми та перспективи застосування методу (огляд літератури)
}

\section{ІНФОРМАЦІЯ}

Надійшла до редакції/Received: 12.11.2019 p.

Ключові слова: ендодонто-ендоосальна імплантація; стоматологічне лікування; експертна оцінка.
АНОТАЦІЯ

Резюме. Відомим методом покращення біомеханічних параметрів стабілізації зубів після проведення оперативного втручання резекції верхівки кореня є їх армування ендодонто-ендоосальними імплантатами. Недивлячись на позитивний клінічний досвід, метод не знайшов широкого розповсюдження в стоматологічній практиці через складність та недосконалість методики проведення самої операції ендодонто-ендоосальної імплантації, відсутність чітких показань до його застосування, короткого терміну функціонування конструкцій у ротовій порожнині, складнощі, пов’язані 3 остеоінтеграцією імплантатів, установлених через ендодонт.

Мета дослідження - провести комплексний аналіз наявних вітчизняних та зарубіжних даних, що стосуються можливостей, проблем реалізації та подальших перспектив застосування методу ендодонто-ендоосальної імплантації у сучасній стоматологічній практиці.

Матеріали і методи. Систематизація наукових публікацій, що стосувалися мети дослідження, проводилась на основі результатів пошукових запитів у системі Google Академія за ключовими словами («ендодонто-ендоосальна імплантація», «ендодонтичні імплантати», «трансдентальна імплантація» та їх аналогів російською та англійською мовами).

Результати досліджень та їх обговорення. В якості найважливіших для урахування у клінічній практиці аспектів процедури ендодонто-ендоосальної імплантації, за даними літературних джерел, необхідо виокремити наступні: оцінку стану зуба, через який безпосередньо буде встановлений EEI; оцінку ступеня рухомості зуба; оцінку ступеня резорбції міжальвеолярних перегородок; оцінку кількості зубів, які мають нагальну необхідність у проведенні імплантації; оцінку величини кісткового післяопераційного дефекту та можливості його заміщення остеопластичним матеріалом.

Висновки. За наявними даними клінічних та лабораторних досліджень використання методу ендодонто-ендоосальної імплантації можна розцінювати як альтернативний підхід щодо оптимізації біомеханічної стабільності та забезпечення сприятливого функціонального прогнозу зуба після проведення процедур із резекцією частини кореня в умовах наявного патологічного чи післяопераційного дефекту навколишньої кісткової тканини. В ході проведеного літературного огляду було ідентифіковано наявний дефіцит даних щодо можливостей застосування методу ендодонто-ендо- 
осальної імплантації у клінічній стоматологічній практиці, відносний низький рівень доказовості представлених результатів попередніх досліджень та відсутність чітких протоколів щодо реалізації даного методу за різних вихідних клінічних умов.

Вступ. За даним релевантних наукових досліджень за останні десять років значно зріс рівень стоматологічної захворюваності серед населення України, що особливо виражено серед дітей та осіб молодого віку, та призводить до виникнення асоційованих ускладнень [13]. Саме тому ендодонтичне лікування зубів займає значне місце серед усіх терапевтичних стоматологічних втручань. Проте рентгенологічний успіх ендодонтичних втручань, недивлячись на значний арсенал медикаментозних засобів та інструментарію, що постійно оновлюється та удосконалюється, за даними окремих літературних джерел не перевищує 50 \% $[5,6]$. Значна поширеність хронічних верхівкових періодонтитів, що супроводжуються деструкцією кісткової тканини альвеолярного відростка, призводить до виникнення потреби у хірургічному лікуванні вказаної патології з метою збереження зубів. Проте після резекції верхівки кореня значно знижуються біомеханічні показники зуба, збільшується функціональне навантаження, виникає патологічна рухомість, що часто призводить до втрати одиниці зубного ряду [7, 8].

Відомим методом покращення біомеханічних параметрів стабільності зубів після проведення оперативного втручання резекції верхівки кореня $є$ ï армування ендодонтоендоосальними імплантатами $[9,10]$. Недивлячись на позитивний клінічний досвід, метод не знайшов широкого розповсюдження в стоматологічній практиці через складність та недосконалість методики проведення самої операції ендодонто-ендоосальної імплантації, відсутність чітких показань до його застосування, короткого терміну функціонування конструкцій у ротовій порожнині, складнощі, пов'язані з остеоінтеграцією імплантатів, встановлених через ендодонт $[9,10]$.

Проте у ряді клінічних випадків, особливо таких, що стосуються лікування фронтальної групи зубів у осіб молодого віку, використання ендодонто-ендоосальних імплантатів після резекції верхівки є альтернативним методом реабілітації зі збереженням естетичного та функціонального результату в різних термінах післяопераційного періоду [9].
Використання методу ендодонто-ендоосальної імплантації також можна розглядати як варіант оптимізації результатів лікування періодонтиту, враховуючи, що дана патологія $є$ однією з основних, яка провокує ранню втрату одиниць зубного ряду та стійкі порушення функції зубощелепного апарату, а також $є$ причиною сенсибілізації та імуносупресії [11]. Крім того, застосування ендодонтичних імплантатів виключає необхідність проведення інвазійних втручань на зубах, що обмежують частковий дефект зубного ряду, та зменшує рівень відносних трудових та матеріальних витрат, пов'язаних із виготовленням різних дизайнів незнімних чи знімних конструкцій для відновлення неперервності зубного ряду $[11,12]$.

Результати класичних досліджень, присвячених оцінці рівня виживання ендодонто-ендоосальних імплантатів, вказують на 91\% виживання даного типу опор протягом п’ятирічного періоду спостереження [13]. Проте враховуючи динамічні тенденції щодо змін поширеності їх використання у клінічній практиці з вираженим трендом до виключення даного типу імплантації як потенційно-доступного методу консервативно-хірургічного лікування, та паралельне проведення низки актуальних досліджень, що стосуються аспектів їх біомеханічного функціонування за різних умов обсягу резекції верхівки кореня, виникає потреба перегляду існуючих на сьогодні актуальних аспектів застосування ендодонто-ендоосальних імплантатів у клінічній практиці. Виокремлення найбільш значущих із них та інформування лікарів-стоматологів щодо особливостей процедури проведення ендодонто-ендоосальної імплантації дозволить сформувати умови для розгляду можливостей застосування даного методу як потенційно ефективного та адаптованого до індивідуальних умов окремих специфічних клінічних ситуацій.

Метою дослідження було провести комплексний аналіз наявних вітчизняних та зарубіжних даних, що стосуються можливостей, проблем реалізації та подальших перспектив застосування методу ендодонто-ендоосальної 
імплантації у сучасній стоматологічній практиці.

Матеріали і методи. Систематизація наукових публікацій, що стосувалися мети дослідження, проводилась на основі результатів пошукових запитів у системі Google Академія за ключовими словами («ендодонто-ендоосальна імплантація", «ендодонтичні імплантати", «трансдентальна імплантація» та їх аналогів російською та англійською мовами). Категоризацію відібраних статей проводили відповідно до наступних критеріїв комбінованого ранжування - релевантність публікації, дата публікації, обсяг цитування. Інтерпретація результатів проведеного контент-аналізу забезпечувалась шляхом порівняння різних характеристик даних, наведених у відібраних дослідженнях, між собою, з урахуванням взаємозв'язків змістовних складових та їх відносної клінічної значимості для практичної стоматологічної діяльності.

Результати досліджень та їх обговорення. 3 усіх видів імплантатів і методів імплантації ендодонто-ендоосальна імплантація (EEI) $€$ однією із найменш вивченою, яка не знайшла широкого застосування в практиці амбулаторної хірургічної стоматології за рядом об'єктивних причин: обмеження показань, ускладнення, що виникають як під час операції, так і у віддалені терміни, відсутність чітких протоколів реалізації [9-12]. Однак за даними літературних джерел, в нерідких випадках EEI можна віднести до методу так званого реанімування зубів у ситуаціях, коли лікар стоїть перед вибором між проведенням екстракції або ж зубозберігальної операції. Остання передбачає резекцію верхівки кореня, після якої метод EEI сприяє вираженому покращенню біомеханічних показників стабільності прооперованих зубів. Найчастіше ендодонто-ендоосальні імплантати використовувалися в комплексній терапії захворювань пародонта, лікуванні травм зубів, в окремих випадках при операції резекції верхівки кореня, при цистектомії із резекцією верхівки кореня, після гемісекції $[9,10]$. За даними П. О. Майструк (2013) використання ендодонто-ендоосальних імплантатів можливе з метою забезпечення шинування окремих одиниць зубного рядку в наступних випадках: при наявності персистуючої рухомості зубів після проведення відповідних оклюзійних корекцій та пародонтологічного лікування; з метою ретенції після завершенню ортодонтичного лікування; у ви- падках виникнення факту гострої дентоальвеолярної травми $[11,12]$.

У низці попередніх досліджень було описано перспективу застосування ендодонто-ендоосальних імплантатів 3 метою лікування пацієнтів із деструктивною формою періодонтитів. Так, зокрема Р. М. Гізатуллін та співавт. (2008) повідомили про позитивний досвід застосування ендодонто-ендоосальних імплантатів із нанофазним біокомпозитним покриттям поверхні, які продемонстрували свою ефективність у більшості проаналізованих випадків лікування деструктивних періодонтитів незалежно від обсягу деструкції навколишньої кісткової тканини та показника віку пацієнта [14]. При цьому автори відмітили два важливі аспекти процедури ендодонто-ендоосальної імплантації: 1) можливість використання в якості опор елементів, виготовлених із нікелід-титану, що характеризуються наявністю функції пам'яті форми, і таким чином, піддаються адаптації до морфологічних особливостей структур ендодонта; 2) можливість застосування біоматеріалів, якими виповнюють простір ендодонта та навколишнього періодонта перед безпосереднім уведенням ендодонто-ендоосального імплантату, що сприяє активації процесів органотипової регенерації та посттравматичної репарації кісткової тканини в ділянці періодонтальної деструкції [14].

Аналогічний підхід був описаний у публікації Т. Ф. Даніліної та колег (2007), в якій було аргументовано доцільність комплексного стоматологічного лікування із застосуванням методу ендодонто-ендоосальної імплантації з використанням пористої гідроксиапатитної кераміки. Використання такого середника, на думку авторів, сприяє стабілізації кісткового регенерату за рахунок його остеокондуктивних характеристик [15]. У дослідженні M. H. Fathi et al. (2013) було відмічено, що покриття поверхні ендодонто-ендоосального імплантату двошаровим гідроксиапатитом/ніобіумом за даними скануючої електронної мікроскопії сприяло підвищенню рівня корозійної резистентності імплантату та зростанню показників його біосумісності [16]. За даними отриманих результатів гістологічних зрізів дослідники зробили висновок про статистичну підтверджену вищу біосумісність ендодонто-ендоосальних імплантатів та формування більш сприятливого кісткового середовища навколо таких опор, порівняно з аналогами 
без відповідного покриття, що використовувалися з аналогічною метою [16]. Хоча результати класичного дослідження F. R. Parreira et al. (1996) вказують на те, що застосування титану як матеріалу виготовлення для ендодонто-ендоосальних імплантатів, характеризується відсутністю епітеліальних чи клітин запалення по всій довжині опори, уведеної у кісткову тканину через простір ендодонта [17]. S. Mittal et al. (2011), у свою чергу, описали результати успішного застосування ендодонто-ендоосальних імплантатів із кобальт-хромового сплаву в якості специфічних ендодонтичних стабілізаторів 3 метою лікування зубів із серединним горизонтальним переломом кореня за даними рентгенологічних досліджень та клінічних спостережень [18]. В умовах лабораторного дослідження було доведено можливість застосування в якості ендодонтальних імплантатів цирконієво-оксидних аналогів конструкцій, остеоінтеграційні властивості котрих залежать від параметрів шорохуватості поверхні, морфології і розмірів кристалів та фаз їхнього співвідношення [19].

3 метою подальшого дослідження методу ендодонто-ендоосальної імплантації М. В. Джамалова та А. Г. Степанов (2017) запропонували оригінальну математичну модель, на основі якої автори досліджували відмінності розподілу напруг у два періоди дослідження: після установки ендодонто-ендоосального імплантату до моменту досягнення стану його інтеграції, та після досягнення інтеграції титанового елемента [20]. Авторам вдалось визначити, що напруги, які виникають в структурі самого імплантату на першому етапі значно зростають із збільшенням обсягу резекції кореня (з 1/3 до 2/3 - на 20-30 \%), проте таких критичних відмінностей не вдалось відмітити при моделюванні остеоінтегрованого стану імплантату [20]. Виходячи 3 цього, дослідники рекомендували забезпечити «щадний режим функціонування" реабілітованої одиниці зубного ряду до моменту досягнення остеінтегрованого стану внутрішньокісткового ретенційного елемента, разом 3 тим, при досягнені такого навіть фактор обсягу резекції демонстрував статистично незначимий рівень впливу на прогноз майбутньої успішності внутрішньоендодонтичного фіксаційного елемента [20].

Особливу увагу плануванню процедури ендодонто-ендоосальної імплантатції було відмічено у роботах О. В. Митченюк (2008), в яких автор відмітив значимість попереднього дослідження морфометричних показників розмірів коронок і коренів зубів, що, у свою чергу, визначають розмірні характеристики майбутньої трансендодонтичної опори для біомеханічно-прогнозованого функціонування [21]. Крім того, автор підкреслював значимість на етапі планування подібної маніпуляції ще і таких параметрів як ступінь навантаження, стан кісткової тканини в області інтересу, розмірні параметри кісткової тканини, розміри висоти коронок та довжини кореня [21]. У публікації Е. А. Базикян та співавт., (2007) було описано новий дизайн ендодонто-ендоосального імплантату, в структурі котрого завдяки профілю різьби вдалось вдвічі зменшити глибину занурення в губчасту кісткову тканину щелеп, зберігаючи при цьому рівні сили витягування [22]. В таких умовах вдається досягнути успішних результатів ендодонто-ендоосальної імплантації навіть в умовах вираженого дефіциту кісткової тканини в периапікальній ділянці. У дослідженні G. Parmar et al. (2000) також був представлений досвід успішного застосування індивідуалізовано-виготовлених ендодонтичних імплантатів, які забезпечили надійне утримання уражених одиниць зубного ряду в структурі альвеолярного гребня [23].

Прогностична успішність ендодонтичних імплантатів за даними Т. Nivethithan et al. (2015) залежить від урахування трьох наступних критеріїв: ефективності апікальної обтурації простору ендодонта конструкцією імплантата-стабілізатора; рівня ретенції імплантата-стабілізатора відносно резидуальних твердих тканин зуба; рівня ретенції імплантата-стабілізатора за межами апекса відносно навколишньої кісткової тканини [24].

Серед невирішених проблем ендодонто-ендоосальної імплантації з точки зору оцінки рівня прогнозованості даного типу втручання виокремлюють наступні:

- відсутність специфічних діагностичних підходів оцінки індивідуальної реакції кісткової тканини та структур пародонта на матеріал імплантату;

- відсутність адаптованої класифікації кісткової тканини та стану ендодонта за ступенем сумісності з імплантатом;

- відсутність алгоритму вибору імплантату з різними покриттями для пацієнтів із різним ступенем імплантофілії;

- відсутність доказових методів регулювання регенерації кісткової тканини при імплан- 
тації та вирішення питання контролю біоадгезії;

- відсутність критеріїв оцінки якості поверхні імплантату та амортизаційних характеристик системи імплантатів.

Серед найважливіших для урахування в клінічній практиці аспектами ендодонто-ендоосальної імплантації за даними літературних джерел необхідно виокремити наступні:

- оцінку стану зуба, через який безпосередньо буде встановлений ЕЕI (питання проведення EEI в бокових ділянках щелеп залишається невирішеною);

- оцінку ступеня рухомості зуба;

- оцінку ступеня резорбції міжальвеолярних перегородок;

- оцінку кількості зубів, які мають нагальну необхідність в проведенні імплантації;

- оцінку величини кісткового післяопераційного дефекту та можливості його заміщення остеопластичним матеріалом.

Таким чином, у ході проведеного огляду літературних джерел вдалось встановити, що за наявними даними клінічних та лабораторних досліджень використання методу ендодонтоендоосальної імплантації можна розцінювати як альтернативний підхід щодо оптимізації біомеханічної стабільності та забезпечення сприятливого функціонального прогнозу зуба в умовах проведення процедур із резекцією частини кореня в умовах наявного патологічного чи післяопераційного дефекту навколишньої кісткової тканини. Оцінка відновлення біомеханічних показників стабілізації зуба 3 резекованою верхівкою кореня, забезпечення надійної і довготривалої фіксації внутрішньокісткової частини EEI, встановлення параметрів оптимальної тривимірної обтурації кореневого каналу фронтальної групи зубів після операції резекції верхівки кореня конструкцією ендодонто-ендоосального стабілізатора, та подальша деталізація особливостей остеоінтеграції імплантатів, встановлених через структуру ендодонта, залишаються актуальними науковими питаннями, що потребують своєчасного вирішення із застосуванням сучасних методів дослідження та аналізу.

Висновки. В ході проведеного літературного огляду було ідентифіковано наявний дефіцит даних щодо можливостей застосування методу ендодонто-ендоосальної імплантації у клінічній стоматологічній практиці, відносний низький рівень доказовості представлених результатів попередніх досліджень та відсутність чітких протоколів щодо реалізації даного методу за різних вихідних клінічних умов. При цьому вдалось чітко категоризувати найбільш проблемні аспекти використання методу ендодонто-ендоосальної у практичній діяльності лікаря-стоматолога, подальше вивчення та вирішення яких сприятиме потенційному перегляду показань та можливостей для його застосування з метою оптимізації біомеханічної стабільності зубів з резекованою верхівкою кореня та наявним післяопераційним дефектом навколишньої кісткової тканини.

\section{(СП. П. Брехличук, П. О. Майструк}

ГВУз «Ужгородский национальный университет»

\section{Эндодонто-эндооссальная имплантация в современной стоматологии: возможности, проблемы и перспективы применения метода (обзор литературы)}

Резюме. Известным методом улучшения биомеханических параметров стабилизации зубов после проведения оперативного вмешательства резекции верхушки корня, является их армирование эндодонто-эндооссальными имплантатами. Несмотря на положительный клинический опыт, метод не нашел широкого распространения в стоматологической практике из-за сложностей проведения и несовершенства методики самой операции эндодонто-эндооссальной имплантации, отсутствия четких показаний к его применению, короткого срока функционирования конструкций в ротовой полости, трудности, связанные с остеоинтеграцией имплантатов, установленных через эндодонт.

Цель исследования - провести комплексный анализ имеющихся отечественных и зарубежных данных, касающихся возможностей, проблем реализации и дальнейших перспектив применения метода эндодонто-эндооссальной имплантации в современной стоматологической практике.

Материалы и методы. Систематизация научных публикаций, касающихся цели исследования, проводилась на основе результатов поисковых запросов в системе Google Академия по ключевым словам 
(«эндодонто-эндооссальная имплантация», «эндодонтические имплантаты», «трансдентальная имплантация» и их аналогов на русском и английском языках).

Результаты исследований и их обсуждение. В качестве важнейших для учета в клинической практике аспектами процедуры эндодонто-эндооссальной имплантации по данным литературных источников следует выделить следующие: оценка состояния зуба, через который непосредственно будет установлен ЭЭИ; оценка степени подвижности зуба; оценка степени резорбции межальвеолярных перегородок; оценка количества зубов, которые имеют насущную необходимость в проведении имплантации; оценка величины костного послеоперационного дефекта и возможности его замещения остеопластическим материалом.

Выводы. По имеющимся данным клинических и лабораторных исследований использование метода эндодонто-эндооссальной имплантации можно расценивать как альтернативный подход к оптимизации биомеханической стабильности и обеспечения благоприятного функционального прогноза зуба после проведения процедур с резекцией части корня в условиях имеющегося патологического или послеоперационного дефекта окружающей костной ткани. В ходе проведенного литературного обзора было идентифицировано имеющийся дефицит данных о возможностях применения метода эндодонто-эндооссальной имплантации в клинической стоматологической практике, относительный низкий уровень доказательности представленных результатов предыдущих исследований и отсутствие четких протоколов по реализации данного метода при различных исходных клинических условий.

Ключевые слова: эндодонто-эндооссальная имплантация; стоматологическое лечение; экспертная оценка.

CP. P. Brechlichuk, P. O. Maistruk

Uzhhorod National University

\section{Endodontic-endosteal implantation in modern dentistry: opportunities, problems and prospects for the application of the method (literature review)}

Summary. Endodontic-endosteal implantation is a well-known method of tooth reinforcement and improvement of its biomechanical stability parameters after surgical intervention with root apex resection. Despite the positive clinical experience, the method is not widespread in dental practice due to the complexity and imperfection of the endodontic-endosteal implantation procedure, the absence of clear indications for its use, short term functioning of the structures in the oral cavity, problems with osseointegration of the implants installed through the endodontist.

The aim of the study - to provide comprehensive analysis of available domestic and foreign data regarding the possibilities, problems of implementation and further prospects of using the method of endodonticendosteal implantation in modern dental practice.

Materials and Methods. The systematization of scientific publications relevant to the aim of the study was based on Google Scholar search queries by keywords ("endodontic-endosteal implantation", "endodontic implants", "transdental implantation" and their analogs in Russian and English).

Results and Discussion. The most important aspects of the endodontic-endosteal implantation procedure according to the literature that need to be consider in clinical practice are the following: assessment of the tooth condition, through which the EEI will be directly installed; assessment of the tooth mobility degree; assessment of the interveolar septa resorption degree; estimation of the number of teeth that have an urgent need for implantation; evaluation of the postoperative bone defect size and the possibility of its replacement by osteoplastic material.

Conclusions. According to the available clinical and laboratory data, the use of endodontic-endosteal implantation can be considered as an alternative approach to optimize biomechanical stability and ensure a favorable functional prognosis of the tooth after procedures with resection of part of the root in the presence of pathological or postoperative tissue defect. A lack of data on the possibilities of using the method of endodontic-endosteal implantation in clinical dental practice, the relatively low level of evidence of the presented results of previous studies and the lack of clear protocols for the implementation of this method during different clinical conditions were identified during review of the literature.

Keywords: endodontic-endosteal implantation; dental treatment; expert evaluation. 


\section{Хірургічна стоматологія}

\section{СПИСОК ЛІТЕРАТУРИ}

1. Клітинська О. В. Функціонально-організаційна модель профілактики та лікування карієсу в дітей Закарпатської області / О. В. Клітинська // Україна. Здоров’я нації. - 2017. - № 3. - С. 134-139.

2. Мельник В. С. Аналіз поширеності захворювань зубощелепної системи, які формують попит на стоматологічні послуги / В. С. Мельник, М. Е. Ізай, Я. І. Дуганчик // Молодий вчений. - 2016. - № 12.1. C. $166-169$.

3. Савичук Н. О. Стоматологічне здоров'я дітей, методологічні підходи та критерії його оцінки / Н. О. Савичук, О. В. Клітинська // Соврем. стоматология. - 2008. - No. 1. - С. 94-98.

4. Friedman S. The success of endodontic therapy healing and functionality / S. Friedman, C. Mor // CDA J. - 2004. - No. 32(6). - P. 493-403.

5. Sathorn C. Effectiveness of single versus multiple visit endodontic treatment of teeth with apical periodontitis: a systematic review and meta analysis / C. Sathorn, P. Parashos, H. H. Messer // International Endodontic Journal. - 2005. - No. 38 (6). - P. 347-355.

6 . Outcomes of nonsurgical retreatment and endodontic surgery: a systematic review / M. Torabinejad, R. Corr, R. Handysides, S. Shabahang // Journal of Endodontics. - 2009 - No. 35 (7). - P. 930-937.

7. Márton I. J. Overlapping protective and destructive regulatory pathways in apical periodontitis / I. J. Marton, C. Kiss // Journal of endodontics. - 2014. - No. 40 (2). P. 155-163.

8. Ørstavik D. Essential endodontology: prevention and treatment of apical periodontitis / D. Ørstavik, T. P. Ford. - Oxford, UK : Blackwell Munksgaard, 2020. - 408 p.

9. Gutmann J. L. Endodontic endosseous implants (diodontic or through the tooth implants)/ J. L. Gutmann, V. Levermann Manjarres // ENDO (London). - 2013. No. 7. - P. 299-304.

10. Endodontic implants / R. K. Yadav, A. P. Tikku, A. Chandra, K. K. Wadhwani // National Journal of Maxillofacial Surgery. - 2014. - No. 5 (1). - P. 70-73.

11. Майструк П. О. Особенности применения эндодонто-эндооссальной имплантации в стоматологии / П. О. Майструк / Стоматолог. - Минск, 2013. - № 3 (10). - С. 85-87.

12. Майструк П. О. Аналіз основних методів стабілізації зубів / П. О. Майструк // Вісник проблем біології і медицини. - 2013. - № 3(2). - С. 25-29.

13. Weine F. S. Survival of the endodontic endosseous implant / F. S. Weine, A. L. Frank // Journal of Endodontics. - 1993. - No. 19 (10). - P. 524-528.

14. Эндодонто-эндоссальная имплантация нанокомпозиционными имплантатами с памятью формы в лечении больных деструктивными периодонтитами / Р. М. Гизатуллин, П. А. Арсеньев, Н. И. Борисенко, Д. В. Гундеров [и др.] // Казанский медицинский журнал. - 2008. - № 89(5). - С. 720-724.

15. Обоснование комплексной методики лечения эндодонто-эндооссальной имплантации с применением пористой гидроксиапатитной керамики / Т. Ф. Данилина, Н. А. Огрина, Т. В. Колесова, B. Н. Наумова // Электронный научнообразовательный вестник «Здоровье и образование в XXI веке». - 2007. - № 9(6). - С. 226.

16. Novel hydroxyapatite/niobium surface coating for endodontic dental implant / M. H. Fathi, M. Salehi, V. Mortazavi [et al.] // Surface Engineering. - 2013. No. 22 (5). - P. 353-358.

17. Histological response to titanium endodontic endosseous implants in dogs / F. R. Parreira, J. D. Bramwell, J. O. Roahen, L. Giambarresi // Journal of Endodontics. - 1996. - No. 22 (4). - P. 161-164.

18. Endodontic stabilizers for treating mid root fractures / S. Mittal, T. Kumar, V. Aggarwal [et al.] // Journal of interdisciplinary Dentistry. - 2011. - No. 1(2). - P. 108110.

19. Trans-endodontic zirconium oxide implants: A Clinical Alternative / L. Aguilera-Galaviz, A. LariosCervantes, H. Flores-Reyes [et al.]//Odovtos International Journal of Dental Sciences. - 2019. - No. 21(1). - P. 15-21. 20. Джалалова М. В. Влияние уровня резекции корня зуба на напряженно-деформированное состояние эндодонто-эндооссального имплантата в зубочелюстном сегменте / М. В. Джамалова, А. Г. Степанов // Российский журнал биомеханики. 2017. - № 21(1). - С. 51-63.

21. Митченюк О. В. Використання морфометричних показників розмірів коронок і коренів зубів при виготовлені ендодонто-ендоосальних імплантатів / О. В. Митченюк // Український стоматологічний альманах. - 2008. - № 3. - С. 12-14.

22. Аспекты применения трансдентальных имплантатов в консервативной и оперативной хирургии зубов / Э. А. Базикян, А. В. Митронин, Ю. М. Максимовский, Т. Г. Робустова // Институт стоматологии. - 2007. - № 1(34). - С. 36-38.

23. Parmar G. Custom-fabricated endodontic implants: report of two cases / G. Parmar, A. V. Pramodkumar // Journal of Endodontics. - 2000. - No. 26 (5). P. 301-303.

24. Thiyagarajah N. Endodontic stabilizers: A Myth / N. Thiyagarajah, S. Ramesh, J. D. Raj // International Journal of Pharmaceutical and Clinical Research. -2015. - No. 7 (2). - P. 132-135

\section{REFERENCES}

1. Klitynska, O.V. (2017). Funktsionalno-orhanizatsiina model profilaktyky ta likuvannia kariiesu $\mathrm{v}$ ditei Zakarpatskoi oblasti [Functional organizational model of prevention and treatment caries in children Transcarpathian region]. Ukraina. Zdorovia natsii Ukraine. Health of Nation, 3, 134-139 [in Ukrainian].

2. Melnyk, V.S., Izai, M.E., \& Duhanchyk, Ya.I. (2016).

Analiz poshyrenosti zakhvoriuvan zuboshchelepnoi systemy, yaki formuiut popyt na stomatolohichni posluhy [Analysis of the prevalence of diseases of the dentition, which form the demand for dental services]. Molodyi vchenyi - Young Scientist, 40 (12.1), 166-169 [in Ukrainian].

3. Savychuk, N.O., \& Klitynska, O.V. (2008). 
Stomatolohichne zdorovia ditei, metodolohichni pidkhody ta kryterii yoho otsinky [Dental health of the children, methodological approaches and criteria for evaluation]. Sovremennaya stomatologiya - Modern Dentistry, (1), 94-98 [in Ukrainian].

4. Friedman, S., \& Mor, C. (2004). The success of endodontic therapy healing and functionality. $C D A$ J, 32(6), 493-503.

5. Sathorn, C., Parashos, P., \& Messer, H.H. (2005). Effectiveness of single versus multiple visit endodontic treatment of teeth with apical periodontitis: a systematic review and meta analysis. International Endodontic Journal, 38 (6), 347-355.

6. Torabinejad, M., Corr, R., Handysides, R., \& Shabahang, S. (2009). Outcomes of nonsurgical retreatment and endodontic surgery: a systematic review. Journal of Endodontics, 35 (7), 930-937.

7. Márton, I.J., \& Kiss, C. (2014). Overlapping protective and destructive regulatory pathways in apical periodontitis. Journal of Endodontics, 40 (2), 155-163.

8. Ørstavik, D., \& Ford, T.P. (Eds.). (2020). Essential endodontology: prevention and treatment of apical periodontitis. Oxford, UK: Blackwell Munksgaard.

9. Gutmann, J.L., \& Levermann Manjarres, V. (2013). Endodontic endosseous implants (diodontic or through the tooth implants). ENDO (London), 7, 299-304.

10. Yadav, R.K., Tikku, A.P., Chandra, A., \& Wadhwani, K.K. (2014). Endodontic implants. National Journal of Maxillofacial Surgery, 5 (1), 70.

11. Maystruk, P.O. (2013). Osobennosti primeneniya endodonto-endoossalnoy implantatsii $\mathrm{v}$ stomatologii [Usage peculiarities of endodonto-endoossal implants in modern dentistry]. Stomatolog. Minsk-Dentist. Minsk, 3 (10), 85-87 [in Russian].

12. Maistruk, P.O. (2013). Analiz osnovnykh metodiv stabilizatsii zubiv [Analysis of main methods for teeth stabilization]. Visnyk problem biolohii i medytsyny - Bulletin of Problems in Biology and Medicine, 3 (2), 25-29.

13. Weine, F.S., \& Frank, A.L. (1993). Survival of the endodontic endosseous implant. Journal of Endodontics, 19 (10), 524-528.

14. Gizatullin, R., Arsenev, P.A., Borisenko, N.Y., Gunderov, D.V., Gufynkel, L. N., Sokov, L.P., ... \& Chekhovoy, A.N. (2008). Endodonto-endossalnaya implantatsiya nanokompozytsyonnimy implantatamy s pamyatyu formu $\mathrm{v}$ lechenii bolnikh destruktyvnimy periodontami [Endodontic-endosal implantiation of nanocomposed implants with a memory of form in treatments of destructive periodontitis]. Kazanskyy meditsynskiy zhurnal - Kazan Medical Journal, 89 (5), 720-724 [in Russian].

15. Danylina, T.F., Ogrina, N.A., Kolesova, T.V., \& Naumova, V.N. (2007). Obosnovanye kompleksnoy metodiky lecheniya endodonto-endoossalnoy implantatsii s prymenenyem porystoy hidroksyapa- tytnoy keramiky [Argumentation of complex treatment method of endodontic-endosteal implantation with the use of porous hydroxyapatite ceramics]. Elektronnyy nauchno-obrazovatelniy vestnyk "Zdorovye $i$ obrazovanye v XXI veke" - Electronic Scientific-Education Bulletin "Health and Education in XXI Century", 9 (6), 226

16. Fathi, M. H., Salehi, M., Mortazavi, V., Mousavi, S. B., \& Parsapour, A. (2006). Novel hydroxyapatite/niobium surface coating for endodontic dental implant. Surface Engineering, 22 (5), 353-358.

17. Parreira, F.R., Bramwell, J.D., Roahen, J.O., \& Giambarresi, L. (1996). Histological response to titanium endodontic endosseous implants in dogs. Journal of Endodontics, 22 (4), 161-164.

18. Mittal, S., Kumar, T., Aggarwal, V., Bansal, R., \& Kaur, D. (2011). Endodontic stabilizers for treating mid root fractures. Journal of Interdisciplinary Dentistry, 1 (2), 108.

19. Aguilera-Galaviz, L., Larios-Cervantes, A., FloresReyes, H., Baltazar, V., \& Gaitan-Fonseca, C. (2019). Trans-endodontic zirconium oxide implants: A clinical alternative. Odovtos International Journal of Dental Sciences, 21 (1), 15-21.

20. Dzhalalova, M.V., \& Stepanov, A. H. (2017). Vliyanye urovnya rezektsiy kornya zuba na napryazhennodeformirovannoye sostoyanye endodonto-endoossalnogo implantata v zubochelyustnom segmente [Influence of tooth root resection level on stress-strain state of endodontic endosseous implant in dentoalveolar segment]. Rossiyskiy zhurnal biomekhaniki - Russian Journal of Biomechanics, 21 (1), 51-63 [in Russian].

21. Mytchenok, O.V. (2008). Vykorystannia morfometrychnykh pokaznykiv rozmiriv koronok i koreniv zubiv pry vyhotovlenni endodontoendoosalnykh implantativ [Use of morphometric parameters of crown and roots size during endodonto endosseous implant fabrication]. Ukrainskyi stomatolohichnyi almanakh - Ukrainian Dental Almanac, (3), 12-14 [in Ukrainian].

22. Bazykyan, E.A., Mytronin, A. V., Maksymovskyy, Yu.M., Robustova, T.H., \& Bazykyan, O.A. (2007). Aspekty prymeneniya transdentalnykh implantatov v konservativnoy i operativnoy khirurgii zubov [Aspects of transdental implants use during conservative and operative surgery of the teeth]. Institut stomatologii - Institute of Dentistry, 1 (34), 36-38 [in Russian].

23. Parmar, G., \& Pramodkumar, A. V. (2000). Customfabricated endodontic implants: report of two Cases. Journal of Endodontics, 26 (5), 301-303.

24. Thiyagarajah, N., Ramesh, S., \& Raj, J.D. (2015) Endodontic stabilizers: A myth. International Journal of Pharmaceutical and Clinical Research, 7 (2), 132-135 